\title{
Class action certification and constitutional claims: The South African case
}

Maastricht Journal of European and Comparative Law 2020, Vol. 27(5) 636-659

(C) The Author(s) 2020 Article reuse guidelines: sagepub.com/journals-permissions DOI: 10.1 I77/1023263X20949685 maastrichtjournal.sagepub.com

\section{Theo Broodryk* ${ }^{*}$}

\begin{abstract}
This article considers whether, in the case of South African, there is a valid basis for requiring certification of certain types of class actions only. Specifically, the article will consider whether a preliminary certification requirement should apply to constitutional claims against the government in the same way it applies to other class actions. To determine this issue, the purpose of certification is considered with a view to establishing whether said purpose is only given effect to in certain circumstances. If certification would serve no purpose in the context of Bill of Rights claims or claims which display a public character, it may be prudent not to require class action certification in such cases. Conversely, if certification would still serve a purpose in those types of cases, it should remain part of class proceedings. To assist in making this determination, the position in several European jurisdictions, Ontario and the United States is considered.
\end{abstract}

\section{Keywords}

Class action, certification, interests of justice, constitution, South Africa

\section{Introduction}

Although class actions were first recognized in the Interim Constitution of the Republic of South Africa, 1993 (Interim Constitution), ${ }^{1}$ it is an area of South African law that remains largely unregulated by statute or court rules. Legislative inaction has compelled the judiciary to step in and, through case law, to develop a structure for the adjudication of class actions. ${ }^{2}$ South African

1. Section 7(4)(b)(iv).

2. See Trustees for the time being of the Children's Resource Centre Trust v. Pioneer Food (Pty) Ltd (Legal Resources Centre as amicus curiae), 20131 All SA 648 (SCA), para. 15, where Wallis JA states as follows: "We are thus

\footnotetext{
* Stellenbosch University, Stellenbosch Central, Stellenbosch, South Africa
}

\section{Corresponding author:}

Theo Broodryk, Stellenbosch University, Stellenbosch Central, Stellenbosch, 7602, South Africa.

E-mail: tbroodryk@sun.ac.za 
superior courts should be commended for developing the existing framework within which class actions operate. The role that the courts have played in this regard is important, especially in view of the increase in recent times in the incidence of class actions. ${ }^{3}$

South African courts have developed the appropriate class action procedural framework using their inherent jurisdiction as entrenched in section 173 of the Constitution of the Republic of South Africa, 1996 (Constitution). This was done in Trustees for the time being of the Children's Resource Centre Trust v. Pioneer Food (Pty) Ltd (Legal Resources Centre as amicus curiae), ${ }^{4}$ which effectively details key aspects of the law relating to class actions in South Africa. The case of Mukaddam v. Pioneer Foods (Pty) Ltd ${ }^{5}$ also created important judicial precedent regarding the South African class action mechanism.

At present, the framework within which class actions operate is mainly based on case law. Courts appear to be developing the procedural framework regulating class actions, and addressing problems that arise in class proceedings, on an ad hoc, case-by-case, basis. Such an approach, although it has been necessitated by legislative inaction, is neither preferable nor desirable. It does not lend itself to creating legal certainty or judicial consistency and uniformity. ${ }^{6}$

Section 38(c) of the Constitution provides as follows:

38. Enforcement of rights - Anyone listed in this section has the right to approach a competent court, alleging that a right in the Bill of Rights has been infringed or threatened, and the court may grant appropriate relief, including a declaration of rights. The persons who may approach a court are- ... (c) anyone acting as a member of, or in the interest of, a group or class of persons...;

Section 38(c) clearly makes provision for class actions within the confines of the Constitution. This means that class action proceedings instituted in terms of section 38 may only be used to enforce rights entrenched in the Bill of Rights. This is the case even in the absence of legislation and court rules that regulate class actions in South Africa. The Supreme Court of Appeal in Permanent Secretary, Department of Welfare, Eastern Cape v. Ngxuza ${ }^{7}$ confirmed that, notwithstanding the absence of class action legislation and court rules, it is possible to use class proceedings to enforce constitutional rights.

confronted with a situation where the class action is given express constitutional recognition, but nothing has been done to regulate it. The courts must therefore address the issue in the exercise of their inherent power to protect and regulate their own process and to develop the common law in the interests of justice'.

3. According to T. Broodryk, 'An Empirical Analysis of Class Actions in South Africa', 24 Law, Democracy and Development (2020), p. 73: 'if one compares the number of cases between 2000 and 2012 and the number of cases between 2013 and 2019, it becomes apparent that there was a significant ( 300 per cent) increase in the incidence of class actions from the first 13-year period to the next seven-year period'.

4. Trustees for the time being of the Children's Resource Centre Trust v. Pioneer Food (Pty) Ltd. (Legal Resources Centre as amicus curiae), 20131 All SA 648 (SCA).

5. Mukaddam v. Pioneer Foods (Pty) Ltd., 201310 BCLR 1135 (CC). The decision of the Supreme Court of Appeal is reported as follows: Mukaddam v. Pioneer Foods (Pty) Ltd., 20132 SA 254 (SCA).

6. Consider, for example, the different conclusions reached in the Mukaddam Supreme Court of Appeal and Constitutional Court judgments regarding whether the existence of exceptional circumstances is indeed a requirement before the opt-in class action mechanism may be utilized.

7. Permanent Secretary, Department of Welfare, Eastern Cape v. Ngxuza, 20014 SA 1184 (SCA). Unlike, for example, rule 23 of the American Federal Rules of Civil Procedure, section 38 of the Constitution does not contain a procedural framework in terms of which a class action is to be conducted. 
Section 38(c) cannot be utilized in the absence of an allegation that a right contained in the Bill of Rights has been threatened or infringed. However, South African law also allows class actions to enforce non-constitutional rights. In other words, it is also possible to institute a class action to enforce rights not contained in the Constitution, such as a claim for damages where no constitutional right was infringed. ${ }^{8}$

In Children's Resource Centre Trust ${ }^{9}$ the Supreme Court of Appeal recognized a class action outside the ambit of the Constitution. ${ }^{10}$ The court dealt with the circumstances when a class action may be instituted and the procedural requirements that must be satisfied before such proceedings may be instituted. In this regard, Wallis JA held that the first procedural step prior to the issuing of summons is to apply to court to certify the process as a class action. ${ }^{11}$ In other words, in class proceedings, a court must first be approached to grant leave for the matter to proceed as a class action. $^{12}$ The class action trial then follows. ${ }^{13}$

Wallis JA laid down the following certification 'requirements', which should guide a court in making its decision regarding whether to certify a class action:

i. There must be a class, identifiable by objective criteria.

ii. There must be a cause of action raising a triable issue.

iii. There must be issues of fact and/or law common to all the members of the class.

iv. The relief sought or damages claimed must flow from the cause of action and must be ascertainable and capable of determination.

v. If the claim is for damages, there must be an appropriate procedure for allocating damages to the class members.

vi. The proposed representative must be suitable to be permitted to conduct the action and to represent the class.

vii. It must be shown that a class action is the most appropriate means of adjudicating the claims of the class members. ${ }^{14}$

In Mukaddam, Jafta J referred to section 173 of the Constitution and confirmed the power of our superior courts to protect and regulate their own processes and, where necessary, to develop the common law to give effect to the interests of justice. Jafta $\mathrm{J}$ held that the interests of justice should be our courts' guiding consideration when deciding whether to certify a class action. ${ }^{15}$

Regarding the certification 'requirements' mentioned in Children's Resource Centre Trust, Jafta J stated as follows:

8. W. de Vos, 'Judicial Activism Gives Recognition to a General Class Action in South Africa', 2 Journal of South African Law (2013), p. 372.

9. Trustees for the time being of the Children's Resource Centre Trust v. Pioneer Food (Pty) Ltd. (Legal Resources Centre as amicus curiae), 20131 All SA 648 (SCA).

10. Ibid., para. 21.

11. Ibid., para. 23-25.

12. It is this process of certification that will form the basis of this article.

13. E. Hurter, 'Class Action: Failure to Comply with Guidelines by Courts Ruled Fatal', 2 Journal of South African Law (2010), p. 2.

14. Trustees for the time being of the Children's Resource Centre Trust v. Pioneer Food (Pty) Ltd. (Legal Resources Centre as amicus curiae), 20131 All SA 648 (SCA), para. 26.

15. Mukaddam v. Pioneer Foods (Pty) Ltd., 201310 BCLR 1135 (CC), para. 33-34. 
In Children's Resource Centre ... the Supreme Court of Appeal laid down requirements for certification. These requirements must serve as factors to be taken into account in determining where the interests of justice lie in a particular case. They must not be treated as conditions precedent or jurisdictional facts which must be present before an application for certification may succeed. The absence of one or another requirement must not oblige a court to refuse certification where the interests of justice demand otherwise. ${ }^{16}$

In other words, according to the Constitutional Court in Mukaddam, the certification 'requirements' laid down in Children's Resource Centre Trust should be treated as a set of relevant 'factors' that have to be taken into account when determining whether or not the class action should be certified. A court is also not limited to considering these factors and may consider other relevant factors not mentioned by Wallis JA. ${ }^{17}$ Further, in examining the prevalence or absence of each or all of the above-mentioned factors, the court's certification decision should be informed by the interests of justice. ${ }^{18}$

South African courts have not been able to address all the problems, contradictions and uncertainties associated with the introduction and development of its class action. One such contradiction and uncertainty relates to the question of whether the process of certification is required for all class actions, or whether it is only required in relation to certain class actions. At present, as will become apparent from the discussion that follows below, there is conflicting authority regarding whether the process of certification of class actions is required in Bill of Rights class actions instituted in terms of section 38(c) of the Constitution against the state. This article will consider the different, often inconsistent, approaches of South African courts in this regard with a view to determining whether Bill of Rights class actions should also be certified. Guidance will be sought from foreign jurisdictions with class actions of general application that also require certification before they may proceed as such.

\section{Case law}

It may at the outset be worthwhile to briefly explain the South African court structure. South Africa has a single national court system. ${ }^{19}$ The different types of ordinary courts include the lower district and regional magistrate's courts, and the South African superior courts, including provincial divisions of the High Court of South Africa, the Supreme Court of Appeal and the Constitutional Court. The Constitutional Court is the highest court in the country, with its decision being binding on all other South African courts. ${ }^{20}$ It is the final court of appeals for all matters $^{21}$ and it has the power to make the final decision on the constitutionality of an act of parliament or of a provincial legislature. ${ }^{22}$ The Supreme Court of Appeal may decide appeals in any matter arising from the High Court of South Africa or a court of a status similar to the High Court of South Africa, except in respect of labour or competition matters to such extent as may

16. Ibid., para. 35 .

17. Ibid., para 47.

18. Nkala and others v. Harmony Gold Mining Company Limited, [2016] 3 All SA 233 (GJ), para. 32.

19. Section 166 of the Constitution.

20. Ibid., section 167(3)(a).

21. Ibid., section 167(3)(b).

22. Ibid., section 167(5). 
be determined by an Act of Parliament. ${ }^{23}$ The High Court and Supreme Court of Appeal may make an order declaring an act to be unconstitutional, but the order must be confirmed by the Constitutional Court. ${ }^{24}$ The provincial divisions of the High Court of South Africa have general jurisdiction over their defined areas, including hearing appeals from the magistrates' courts within their area, and acting as a court of first instance for cases outside the jurisdiction of the magistrates' courts. ${ }^{25}$

South Africa is also divided into numerous magisterial districts with each district being served by a district magistrate's court. They can hear civil cases where the value of the claim does not exceed R200,000. The magisterial districts are grouped into regions and each region has a regional court. Regional courts can hear civil cases where the value of the claim does not exceed R400,000. ${ }^{26}$ Class actions in South Africa are primarily the domain of the High Court of South Africa and may also be adjudicated upon by the Supreme Court of Appeal and the Constitutional Court.

The article will now consider the manner in which South African courts have approached the issue of certification in class actions based on section 38(c) of the Constitution.

\section{A. Trustees for the time being of the Children's Resource Centre Trust and others v. Pioneer Food (Pty) Ltd and others (Legal Resources Centre as amicus curiae)}

In Children's Resource Centre Trust, as mentioned above, Wallis JA extended the class action to non-Bill of Rights matters. ${ }^{27}$ It is worth repeating what he stated regarding the certification requirement in class actions in South Africa:

All of the parties accepted that it is desirable in class actions for the court to be asked at the outset, and before issue of summons, to certify the action as a class action... In my view, they were correct to do so and we should lay it down as a requirement for a class action that the party seeking to represent the class should first apply to court for authority to do so. My reasons for adopting that requirement are the following. Most jurisdictions around the world require certification either before institution of the class action or at an early stage of the proceedings. The exception is Australia. The justifications are various. First, in the absence of certification, the representative has no right to proceed, unlike litigation brought in a person's own interests. Second, in view of the potential impact of the litigation on the rights of others it is necessary for the court to ensure at the outset that those interests are properly protected and represented. Third, certification enables the defendant to show at an early stage why the action should not proceed. This is important in circumstances where the mere threat of lengthy and costly litigation may be used to induce a settlement even though the case lacks merit. Fourth, certification enables the court to oversee the procedural aspects of the litigation, such as notice and discovery, from the outset. Fifth, the literature on class actions suggests that, if the issues surrounding class actions, such as the definition of the class, the existence of a prima facie case, the commonality of issues and the appropriateness of the representative are dealt with and disposed of at the certification stage, it facilitates the conduct of the litigation, eliminates the need for interlocutory procedures and may hasten settlement.

23. Ibid., section 168(3)(a).

24. Ibid., section 167(5).

25. Ibid., section 169(1).

26. Section 29 of the Magistrates' Courts Act 32 of 1994.

27. Trustees for the time being of the Children's Resource Centre Trust v. Pioneer Food (Pty) Ltd. (Legal Resources Centre as amicus curiae), 20131 All SA 648 (SCA), para. 19-21. 
Lastly, the Australian experience has not proved entirely satisfactory, with numerous interlocutory applications and significant costs and delays being experienced. ${ }^{28}$

By stating that 'we should lay it down as a requirement for a class action that the party seeking to represent the class should first apply to court for authority to do so', Wallis JA made no mention of limiting this requirement to certain types or categories of class actions. He did not say that the process of certification is limited to class actions instituted in terms of the common law and that it is not necessary to obtain certification against the state and/or private persons in section 38(c) class actions. It would accordingly seem that Wallis JA intended for the process of certification to be a requirement for all class actions, not just for certain types of class actions, such as non-Bill of Rights class actions.

\section{B. Mukaddam v. Pioneer Foods (Pty) Ltd and others (Legal Resources Centre as amicus curiae)}

In the majority judgment of Mukaddam, ${ }^{29} \mathrm{Jafta} \mathrm{J}$ emphasized the importance of the certification process stating that the '[c] ourts must embrace class actions as one of the tools available to litigants for placing disputes before them. However, it is appropriate that the courts should retain control over class actions'. ${ }^{30} \mathrm{He}$ added that class actions may be oppressive in some instances and, therefore, it is necessary for the courts to have the power 'to keep out of the justice system class actions which hinder, instead of advancing, the interests of justice'. Thus, according to Jafta J, 'prior certification will serve as an instrument of justice rather than a barrier to it'.

However, Jafta $\mathrm{J}$ went further and mentioned obiter that the certification requirement laid down in Children's Resource Centre Trust does not apply to actions in which the enforcement of rights entrenched in the Bill of Rights is sought against the state:

Proceedings against the State assume a public character which necessarily widens the reach of orders issued to cover persons who were not privy to a particular litigation. Class actions in those circumstances are regulated by section 38 which confers, as of right, the authority to institute a class action on certain persons, defined in the section. Moreover, claims for enforcing rights in the Bill of Rights may even be brought in the wider public interest without certification. ${ }^{32}$

The court left open the question of whether the institution of a class action to enforce a right in the Bill of Rights against a private litigant, requires prior certification. The issue was not canvassed before the court and the interpretation of section 38 of the Constitution was not placed in issue. According to Jafta $\mathrm{J}$, '[i]n these circumstances it is neither prudent nor necessary to pronounce on whether prior certification must be obtained for class actions instituted in terms of section 38, without interpreting the section., 33

28. Ibid., para. 23-25.

29. Per Jafta J, with Moseneke DCJ, Khampepe, Nkabinde and Zondo JJ and Bosielo AJ concurring.

30. Mukaddam v. Pioneer Foods (Pty) Ltd., 201310 BCLR 1135 (CC), para. 38.

31. Ibid., para 38.

32. Ibid., para 40. See also W. de Vos, 'Opt-in Class Action for Damages Vindicated by Constitutional Court: Mukaddam v. Pioneer Foods CCT 131/12', 4 Journal of South African Law (2013), p. 767, regarding the reason why Jafta J's comments are regarded as being made obiter.

33. Mukaddam v. Pioneer Foods (Pty) Ltd., 201310 BCLR 1135 (CC), para 41. 
Mhlantla AJ concurred with the judgment of Jafta $\mathrm{J}$ save for those portions of the majority judgment that limited the certification requirement to class actions involving Bill of Rights claims. She found that, given the rationale for certification and the nature of class actions, the benefits of the certification process should apply in all class action suits. ${ }^{34}$ This author, for the reasons indicated later in this article, agrees with Mhlantla AJ that certification should be required for Bill of Rights class actions against government and private persons.

\section{Magidiwana and others v. President of the Republic of South Africa and others (No I)}

In Magidiwana and others $v$. President of the Republic of South Africa and others (No 1), ${ }^{35}$ the applicants sought certification of a class action instituted in terms of section 38 of the Constitution against the state. ${ }^{36}$ The court held that ' $[t]$ he requirement that, applicants in a certification class action application must first meet the criteria, prior to instituting the main action is important, and cannot be ignored'. ${ }^{37}$ The court considered the factors laid down by Wallis JA in Children's Resource Centre Trust, as well as the urgency of the matter in casu, and certified the class action. ${ }^{38}$

\section{Road Freight Association v. Chief Fire Officer Emakhazeni}

In Road Freight Association v. Chief Fire Officer Emakhazeni ${ }^{39}$ the court held that it was satisfied that there were constitutional rights involved in the proposed class action, which involved an unlawful exercise of public power. ${ }^{40}$ The court found that certification in the matter would be in the interest of justice and, having regard to the certification factors laid down by Wallis JA in Children's Resource Centre Trust, certified the class action. ${ }^{41}$

\section{E. Nkala and others v. Harmony Gold Mining Company Ltd and others (Treatment Action Campaign NPC and another as amici curiae)}

The court in Nkala and others v. Harmony Gold Mining Company Ltd and others (Treatment Action Campaign NPC and another as amici curiae) $)^{42}$ confirmed that Wallis JA in Children's Resource Centre Trust did not restrict the certification prerequisite to cases where no right contained in the Bill of Rights has been invoked. ${ }^{43}$ The amici in Nkala contended that certification is unnecessary in a section 38 (c) class action. ${ }^{44}$ The court held that it disagreed with this contention, that is, it held that certification is indeed required for Bill of Rights class actions:

34. Ibid., para. 59-63.

35. Magidiwana and others v. President of the Republic of South Africa and others, (No 1) [2014] 1 All SA 61 (GNP).

36. Ibid., para. 20.

37. Ibid., para. 27.

38. Ibid., para. 25-27.

39. Road Freight Association v. Chief Fire Officer Emakhazeni, [2015] JDR 1802 (GP).

40. Ibid., para. 29.

41. Ibid., para. 30 and 33 .

42. Nkala and others v. Harmony Gold Mining Company Ltd and others (Treatment Action Campaign NPC and another as amici curiae), [2016] 3 All SA 233 (GJ).

43. Ibid., para. 35 .

44. Ibid., para. 38 . 
We are unable to agree with them for two simple reasons, namely that, (i) it can lead to an abuse of court process and, (ii) that it can, as has occurred in Australia, cause numerous costly and timeconsuming interlocutory skirmishes around the very issues that the certification court ought to resolve. The need for the court to protect its own process does not disappear in a matter where a right in the Bill of Rights has been invoked. Section 173 of the Constitution makes it plain that the court has inherent power to protect its own processes.

Accordingly, in Magidiwana and Road Freight Association the courts did not adopt the obiter dicta in Mukaddam that Bill of Rights class actions against organs of state do not need to be certified. Similarly, the court in Nkala confirmed that certification is indeed necessary for Bill of Rights class actions to be certified.

\section{F. Mshengu and others v. Msunduzi Local Municipality and others}

The most recent judgment in which a South African superior court considered whether certification is required in a class action based on section 38(c) of the Constitution, is Mshengu and others $v$. Msunduzi Local Municipality and others. ${ }^{45}$

The applicants launched an application in their own interest; as members of a class of farm occupiers and labour tenants who do not have access to basic services; on behalf of farm occupiers and labour tenants who did not have access to basic services; and in the public interest. The first respondent raised a point in limine, that the third applicant (a non-governmental organization working on land rights and agrarian reform) did not have locus standi to represent unidentified farm occupiers and labour tenants whose area of residence is not disclosed, and, that the third applicant was required to join all the landowners who had farm occupiers and labour tenants residing on farms within the first respondent municipality's area of jurisdiction.

The applicants argued that the relief sought includes the enforcement of rights entrenched in the Bill of Rights against respondents who are organs of state in the public interest. Regarding this contention, Mnguni J held that the applicants 'correctly submitted that the requirement relating to the certification of class actions does not apply to matters wherein members of a class seek to enforce rights entrenched in the Bill of Rights against the State, and, that the contention that all cases brought in terms of section $38(\mathrm{c})$ of the Constitution require certification by the High Court is misplaced. ${ }^{46}$

The court referred to Lawyers for Human Rights and another v. Minister of Home Affairs and another, ${ }^{47}$ where the Constitutional Court held as follows:

Section 38 introduces far-reaching changes to our approach to standing which takes account of, among other things, the vulnerability of the people previously disadvantaged by apartheid, their socioeconomic plight and a concomitant desire to correct the wrongs perpetrated against them over a long period of time. $^{48}$

Mnguni J also referred to Giant Concerts CC v. Rinaldo Investments (Pty) Ltd and others, ${ }^{49}$ where the Constitutional Court held that it is important to emphasise that the broad ambit of

45. Mshengu and others v. Msunduzi Local Municipality and others, [2019] 4 All SA 469 (KZP).

46. Ibid., para. 22.

47. [2004] 4 SA 125 (CC).

48. Ibid., para. 74 .

49. [2013] 3 BCLR 251 (CC). 
constitutional standing must be preserved even for own-interest challenges' ${ }^{50}$ The Constitutional Court in Giant Concerts $C C$ further stated that this approach was necessary 'to facilitate the protection of the Constitution' because 'constitutional litigation is of particular importance in our country where we have a large number of people who have had scant educational opportunities and who may not be aware of their rights'. 51

The court ultimately referred to the obiter dicta in Mukaddam mentioned above and held that, as the case concerns enforcement of rights contained in the Bill of Rights against organs of state for ordinary constitutional claims brought on behalf of a class in terms of section $38(\mathrm{c})$, certification is unnecessary. ${ }^{52}$

Regrettably, apart from referring to Mukaddam, Mnguni J made no reference in the Mshengu judgment to any of the other judgments referred to above.

\section{G. Current legal position}

In view of the above, as the law currently stands, certification is required for all class actions in most South African superior courts. However, as a result of Mshengu, where the court adopted the obiter dicta of the Constitutional Court in Mukaddam, the Kwazulu-Natal Division of the High Court of South Africa follows a different approach, namely one in which certification is not required in Bill of Rights class actions against organs of state. ${ }^{53}$ This approach is not binding on the other divisions of the High Court of South Africa, although it may have persuasive value. Although the need to certify Bill of Rights class actions against private persons has been questioned, ${ }^{54}$ at present certification for such class actions is also required.

As Mshengu represents the only superior court judgment in which it was conclusively held that certification of Bill of Rights class actions is not required, it is too early at this stage to conclude that the case represents a possible future trend as opposed to being a singular outlier. As mentioned, Mshengu adopted the obiter dicta in Mukaddam in finding that certification is not required for Bill of Rights class actions against organs of state. It is unclear why the court followed this approach, notwithstanding numerous other judgments in which the superior courts have confirmed that certification is indeed required for such class actions. As indicated above, these judgments include Children's Resource Centre Trust, Magidiwana, Road Freight Association and Nkala.

As far as the author is aware, there is no other South African superior court case which supports the approach that certification of Bill of Rights class actions is not required. ${ }^{55}$ Indeed, the overwhelming majority of authority supports the adoption of the factors outlined in Children's Resource Centre Trust in all cases, even those brought directly under section 38 of the Constitution. It will be argued below that the approach adopted by the High Court in Mshengu is flawed and that certification of class actions instituted in terms of section 38 should also be required.

50. Ibid., para. 47.

51. Ibid., para. 39.

52. Mshengu and others v. Msunduzi Local Municipality and others, [2019] 4 All SA 469 (KZP)., para. 40.

53. Although it is questionable to what extent the court was permitted to deviate from the decision in Children's Resource Centre Trust, the latter being a decision handed down by the South African Supreme Court of Appeal.

54. Mukaddam v. Pioneer Foods (Pty) Ltd., [2013] 10 BCLR 1135 (CC), para. 41.

55. In T. Broodryk, 24 Law, Democracy and Development (2020), p. 54, the author lists all the South African class action certification judgments up to the end of November 2019. 


\section{Foreign perspective}

The following part of this article will provide a brief overview of various foreign jurisdictions that employ a class action in relation to general types of claims and that also require certification.

\section{A. Ontario and the United States}

Apart from being regarded as the leaders in the field of class action litigation, ${ }^{56}$ the Ontario and American systems of civil procedure are, as in the case of South Africa, of common law origin and the adversary system of litigation is a characteristic of all of them. The basic principles that underlie these systems are similar. ${ }^{57}$ These jurisdictions all trace their origins to the unwritten practices of English Chancery. Today, however, class actions in these jurisdictions are largely creatures of statute and rule. $^{58}$

Rule 23 of the American Federal Rules of Civil Procedure (Federal Rules) and the Class Action Fairness Act of 2005 govern class actions in federal courts in the United States. Rule 23 makes provision for three categories of class actions: rule 23(b)(1) provides for two types of so-called 'prejudice' class actions; rule 23(b)(2) provides for declaratory and injunctive relief; and rule 23(b)(3) provides for the opt-out damage class action. The most important of these categories are class actions to obtain declaratory or injunctive relief and actions for damages. According to Klonoff, ${ }^{59}$ most class actions are brought and certified under rules 23(b)(2) and 23(b)(3). Rule 23(b)(1) is used less frequently. Further, most rules that regulate class actions in America are based on an opt-out rather than an opt-in mechanism.

Rule 23(b)(1) and (b)(2) classes are known as 'mandatory' classes because a judgment is binding on all class members - no class member may opt out and rule 23 does not require notice in such actions. The rationale for the absence of these due process protections for rule 23(b)(1) and (b)(2) classes is based on the members having the same or similar interests and are not pursuing individual damage claims. In the latter circumstances, some class members may have a high interest in opting out of the class action to pursue individual monetary recovery. ${ }^{60}$

The threshold requirements for certification of a class action in the United States are contained in rule 23(a) of the Federal Rules. These certification requirements are generally referred to as numerosity, commonality, typicality, and adequacy of representation. In addition to having to satisfy the requirements for certification, including the numerosity requirement, each class action must satisfy the requirements of either rules 23(b)(1), 23(b)(2) or 23(b)(3). Rule 23(b)(3) pertains to the opt-out damages class action and specifically requires that a court assesses whether class action proceedings is 'superior to other available methods for fair and efficient adjudication of the controversy'. The superiority requirement 'reflects a broad policy of economy in the use of

56. D.L. Bassett, 'The Future of International Class Actions', 18 Southwestern Journal of International Law (2011), p. 22-24.

57. W. de Vos, “n Groepsgeding in Suid-Afrika' 3 Journal of South African Law (1985), p. 304.

58. E. Hurter, 2 Journal of South African Law (2010), p. 413 states that the class action is effectively an American phenomenon and that other Anglo-American jurisdictions that have opted for formal class action devices have been influenced by the American class action. According to Hurter, it is clear that South African class action developments mirror this trend.

59. R.H. Klonoff, Class Actions and Other Multi-party Litigation in a Nutshell (4th edition, West, 2012 ), p. 75.

60. L.S. Mullenix, 'Re-Interpreting American Class Action Procedure: The United States Supreme Court Speaks', 5 ZZP Int (2000), p. 342-343. 
society's difference-settling machinery'. ${ }^{61}$ Rule 23 lists four factors that must be considered by a court in making this assessment:

A. the class members' interests in individually controlling the prosecution or defence of separate actions;

B. the extent and nature of any litigation concerning the controversy already commenced by or against class members;

C. the desirability or undesirability of concentrating the litigation of the claims in the particular forum; and

D. the likely difficulties in managing a class action. ${ }^{62}$

In Lake v. First Nationwide Bank ${ }^{63}$ it was held that, in performing the superiority analysis, the court must consider the 'inability of the poor or uninformed to enforce their rights, and the improbability that large numbers of class members would possess the initiative to litigate individually'. Specifically, the manageability requirement in rule 23(b)(3)(D) 'encompass[es] the whole range of practical problems that may render the class action format inappropriate for a particular suit' ${ }^{64}$ It entails that a court focuses on the advantages of a class action compared to alternative forms of dispute resolution which may be available to the claimants, such as litigation through joinder. In re Managed Care Litigation ${ }^{65}$ it was held that this consideration 'requires the Court to determine whether there is a better method of handling the controversy other than through the class action mechanism'. In Carnegie v. Mutual Saving Life Insurance Company ${ }^{66}$ it was held that, where management problems may result in class proceedings being less fair and efficient than other dispute resolution methods, then a class action would be improper.

Furthermore, certification under rule 23(b)(3) requires that a question of law or fact common to the class predominate over any questions affecting only individual class members and that a class action be superior to other available methods for a fair and efficient adjudication of the controversy. ${ }^{67}$ 'In order to meet the predominance requirement of rule 23(b)(3), a plaintiff must establish that "the issues in the class action that are subject to generalized proof, and thus applicable to the class as a whole,... predominate over those issues that are subject only to individualized proof". ${ }^{68}$ In other words, when one or more of the central issues in the action predominates, the action can be maintained pursuant to rule 23(b)(3) even though other significant issues may have to be tried separately. For example, predominance may be found even in cases where damages must be determined individually. However, it has been proposed that, if the central issues in the case require the separate adjudication of each class member's individual claim or defence, a rule 23(b)(3) class action is usually inappropriate. ${ }^{69}$

61. Berley v. Dreyfus \& Co., 43 F.R.D. 397, 398 (S.D.N.Y. 1967).

62. Rule 23(b)(3)(A)-(D) of the Federal Rules of Civil Procedure.

63. 156 F.R.D. 615, 625 (E.d.Pa. 1994).

64. Eisen v. Carlisle \& Jacquelin, 417 U.S. 156, 164 (1974).

65. 209 F.R.D. 678, 692 (S.D. Fla. 2002).

66. No. CV-99-S-3292-NE, 2002 U.S. Dist. LEXIS 21396, at 76-77 (N.D. Ala. Nov. 1, 2002).

67. See Danvers Motor Co v. Ford Motor Co 543 F.3d 141, 148 (3d Cir 2008) '[w] here an action is to proceed under rule 23(b)(3), the commonality requirement is subsumed by the predominance requirement'.

68. Runstein v. Avis Rent-A-Car Sys., Inc,. 211 F.3d 1228, 1233 (11th Cir. 2000).

69. M.H. Greer, A Practitioner's Guide to Class Actions (ABA Publishing, 2010), p. 85. 
Federal Rule 23(b)(2) may be used for civil rights-based claims. ${ }^{70}$ Rule 23(b)(2) provides that '[a] class action may be maintained if Rule 23(a) is satisfied and if . . the party opposing the class has acted or refused to act on grounds that apply generally to the class, so that final injunctive relief or corresponding declaratory relief is appropriate respecting the class as a whole ... ${ }^{71}$ The subrule allows a court to determine whether the defendant's behaviour is legal in regards to the entire class, rather than through piecemeal litigation. ${ }^{72}$ If the court decides in favour of the class, all class members can rely on the resulting injunction or declaration. If the court decides in favour of the defendant, all class members are bound to that result. ${ }^{73}$

Perhaps a word of caution at this stage is prudent. Unclear certification requirements also have the potential to stifle access to justice. In Vallario $v$. Vandehey ${ }^{74}$ the respondents - prison inmates sought class certification under rule 23(b)(2) against the government of the United States. ${ }^{75}$ The respondents argued that numerous jail customs and policies, or the lack thereof, contributed to the alleged violation of inmates' constitutional rights. The 10th Circuit granted the appellants' petition for review and remanded for the district court to reconsider its class certification order. The court held that the certification ruling had been based on an 'unduly constrained view of the inquiry authorized by Rule 23'. ${ }^{76}$ According to Baldock J, the rule 23 requirements overlap with the merits and, in conducting a rigorous rule 23 analysis, the merits would also need to be considered to a certain extent. ${ }^{77} \mathrm{He}$ further held that the district court also erred in failing to hold the respondents to their burden under Rule 23(b)(2). ${ }^{78}$ In this regard, according to Baldock J, the 'Respondents cannot demonstrate, without more, that "injunctive relief - relative to the class - is conceivable and manageable without embroiling" the district court "in disputes over individualized situations and constantly shifting class contours.",79 The relief sought was thus found not to have been detailed with sufficient specificity. ${ }^{80}$

However, in a concurring judgment, Kelly $\mathrm{J}$ opined as follows:

I am concerned by this court's suggestion ... that apparently seeks to impose significantly more than is called for under Rule 23(b)(2) upon those seeking class certification. The rule merely requires pleading facts that would reflect 'the party opposing the class has acted or refused to act on grounds that apply generally to the class, so that final injunctive relief ... is appropriate respecting the class as a whole.' It is up to the district court to construct an appropriate order after hearing the evidence and neither Rule

70. S. Malveaux, 'A Diamond in the Rough: Trans-Substantivity of the Federal Rules of Civil Procedure and its Detrimental Impact on Civil Rights', 92 Washington University Law Review (2014), p. 484-508 notes that 'the class action device... plays a special role in the civil rights context'.

71. According to B. van Schaack, 'Unfulfilled Promise: The Human Rights Class Action' 1 University of Chicago Legal Forum (2003), p. 279: 'Since the late 1980s, victims of human rights violations have increasingly utilized Federal Rule of Civil Procedure 23 ("Rule 23"), which governs the certification and conduct of the class action in federal court'.

72. Federal Rule of Civil Procedure 23 advisory committee's note to 1966 amendment.

73. See, for example, Brown v. Bd. of Educ., 347 U.S. 483, 495 (1954).

74. 554 F. 3d 1259 (10th Cir. 2009).

75. More specifically, against Petitioners Lou Vallario, the Sheriff of Garfield County, and Scott Dawson, the commander charged with administering jail operations.

76. 554 F. 3d 1259 (10th Cir. 2009), p. 1267.

77. Ibid.

78. Ibid.

79. Ibid., p. 1268 .

80. Ibid. 
23(b)(2) or Rule 65(d) impose any 'specificity requirement' on the moving party other than as above noted. ${ }^{81}$

The different interpretations afforded to the certification requirements under rule 23 in Vallario serves as a prudent reminder that unclear certification requirements have the potential to hamper individuals' access to justice. Although both judges agreed that the decision should be remanded for the district court to reconsider its class certification order, it renders conceivable that certification could, where the nature and scope of requirements are unclear and open to interpretation, unduly complicate the litigation and prevent litigants from having the merits of their dispute adjudicated in court. Stated differently, when certification of class actions is required, the certification factors or requirements, and the confines within which the certification decision must be taken, should be clear and unambiguous.

In Ontario, Canada, ${ }^{82}$ the Ontario Class Proceedings Act of 1992 (Ontario Act), which is based largely on a comprehensive report delivered by the Ontario Law Reform Commission in 1982 and the recommendations contained therein, deals comprehensively with all aspects relating to class actions in Ontario. ${ }^{83}$ The Ontario Act provides for a general class action and it regulates similar matters as provided for in rule 23 of the Federal Rules, but it does so in much more detail. The United States and Ontario regarded the common law rule on representative actions as inadequate to deal with the current complex nature of class actions. ${ }^{84}$ In Ontario, the class action can be used to litigate matters with a public interest component, to bring constitutional challenges and claims regarding the activities of government entities. ${ }^{85}$

In Ontario, similar to South Africa and the United States, a class action cannot be commenced without certification by a court. Section 5(1) of the Ontario Act provides that a class action should be certified where the following criteria are met:

a. the pleadings or the notice of application discloses a cause of action;

b. there is an identifiable class of two or more persons that would be represented by the representative plaintiff or defendant;

c. the claims or defences of the class members raise common issues;

d. a class proceeding would be the preferable procedure for the resolution of the common issues; and

e. there is a representative plaintiff or defendant who:

81. Ibid., p. 1270-1271.

82. The Canadian constitution assigns jurisdiction over property and civil rights to the provinces. Class actions thus proceed through the superior courts of each province.

83. According to Y. Martineau and A. Lang, 'Canada', in P.G. Karlsgodt (ed.), World Class Actions - A Guide to Group and Representative Actions around the Globe (Oxford University Press, 2012), p. 57, with the exception of the province of Quebec, which is a civil law jurisdiction, all Canadian provinces and territories are common law jurisdictions.

84. W. de Vos, 'Is a Class Action a "Classy Act" to Implement Outside the Ambit of the Constitution?', 4 Journal of South African Law (2012), p. 744.

85. See, for example, Fresco v. Canadian Imperial Bank of Commerce, 2012 ONCA 444; Fulawka v. Bank of Nova Scotia, 2012 ONCA 443; Seed v. Ontario, 2012 ONSC 2681; See also Law Commission of Ontario, Review of Class Actions in Ontario (2013), p. 2 and 6; and G.D. Watson, 'Class Actions: The Canadian Experience', 11 Duke Journal of Comparative and International Law (2001), p. 272: 'The procedures provided by the legislation in each of the three provinces are structurally similar to those prescribed by Rule 23 of the U.S. Federal Rules of Civil Procedure, although in certain respects the Canadian legislation is more liberal in facilitating class actions than its American counterpart.' 
i. would fairly and adequately represent the interests of the class,

ii. has produced a plan for the proceeding that sets out a workable method of advancing the proceeding on behalf of the class and of notifying class members of the proceeding; and

iii. does not have, on the common issues for the class, an interest in conflict with the interests of other class members.

The class actions of Ontario and the United States do not limit the requirement of certification to only certain types of class actions, although depending on the nature of the class action pursued, as mentioned above, there may be additional requirements which need to be complied with. Certification is required in all class actions, regardless of the nature of the claim and whether government is involved.

\section{B. Europe}

Within the European Union, there are a limited number of Member States that have collective action regimes of general application. All these regimes require some type of certification. Brief mention of these jurisdictions is made herein below.

The Swedish Group Proceedings Act $2002^{86}$ entered into force on 1 January 2003. It contains specific procedural rules on group actions which are applicable to all civil claims. In other words, the Group Proceedings Act is not restricted to certain areas of civil law. A group action is commenced upon the filing of a summons application in accordance with the Swedish Code of Judicial Procedure. ${ }^{87}$ The summons application is considered by the court as would usually be the case when pursuing individual proceedings. However, a class action will only be heard by the court if certain specific conditions are satisfied:

i. the action must be based on circumstances that are common or similar to the claims of the members or the group;

ii. group proceedings must not appear to be inappropriate having regard to the claims of group members;

iii. it should not be possible to equally and adequately pursue most of the claims through personal actions by the individual members of the group;

iv. the group must be appropriately defined, taking into consideration its size, scope and other factors;

v. the claimant must be able to appropriately represent the members of the group, having regard to its interest in the substantive matter, its financial capacity to bring a group action and the general circumstances of the case;

vi. a private group action and an organization action must be brought by a member of the Swedish Bar Association (advokat).

If the court finds that all the conditions above are satisfied, the action will proceed as a group action under the Group Proceedings Act. Otherwise, the court will dismiss the action. All forms of redress that are available under usual civil litigation rules are also available in class actions. ${ }^{88}$

86. Sw. lag (2002:599) om grupprättegång.

87. Sw. Rättegångsbalk 1942:740.

88. Sw. Konkurrensskadelag 2016:964 (section 2 of the Act); C.I. Nagy, Collective Actions in Europe A Comparative, Economic and Transsystemic Analysis (2019, Springer), p. 87 and 90-91. 
The Bulgarian opt-out collective action scheme inserted into the Code of Civil Procedure of 2007 also covers all violations of law. ${ }^{89}$ A collective action may be launched in Bulgaria if the following requirements are met:

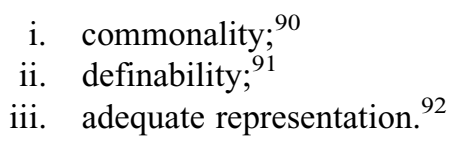

Similarly, the Danish rules on collective actions, effective 1 January $2008,{ }^{93}$ introduced a generally applicable ${ }^{94}$ system where it is up to the judge to decide whether to approve the collective action under the opt-in or the opt-out scheme. ${ }^{95}$ A collective action may be initiated, if the following conditions are met:

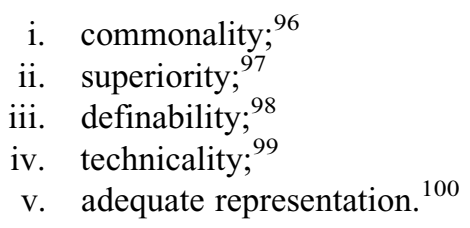

89. Promulgated in State Gazette No. 59/20.07.2007, amended and supplemented by SG No. 50/30.05.2008, modified by Judgment No. 3 of the Constitutional Court of the Republic of Bulgaria of 8.07.2008 - SG No. 63/15.07.2008, amended by SG No. 69/5.08.2008. The class action provisions can be found in Chapter 33, Sections 379-388 of the Bulgarian Code of Civil Procedure.

90. A collective action may be certified if group members' common interests were impaired by the same infringement and this may give rise to similar legal consequences for all of them.

91. Group members are identifiable.

92. It has to be proved that the group representative has the capacity 'to protect the harmed interest seriously and in good faith, as well as to incur the charges related to the conduct of the case, including the costs'; see sections 379(1), 380(3) and 381(1) of the Bulgarian Code of Civil Procedure. C.I. Nagy, Collective Actions in Europe A Comparative, Economic and Transsystemic Analysis (2019), p. 84 and 90.

93. Following recommendation no. 1468/2005 by the Standing Committee on Procedural Law (Retsplejerådet).

94. The group action regime applies to all claims, except for the ones listed in Administration of Justice Act chapters 42 (matrimonial or parental cases), 42a (paternity cases), 43 (guardian cases), 43a (administrative determination of detention), 43b (examination of adoption decision without consent), 44 (acquisition of mortgaging or property judgment) and 88 (private criminal matters).

95. Following recommendation no. $1468 / 2005$ by the Standing Committee on Procedural Law (Retsplejerådet), the possibility of class actions with effect for cases brought on or after 1 January 2008 was introduced into Danish law.

96. The parties dispose of a common claim arising from the same factual and legal basis.

97. The collective action is the best mechanism to settle the claims. This condition is met, if the collective action is more expedient than traditional joinder of parties.

98. Group members are identifiable and may be informed in an appropriate manner.

99. The judge disposes of the expertise required to adjudicate the claims.

100. An appropriate person can be appointed as the group's representative. The legal basis of the class action regime is chapter 23a, sections 254a to $254 \mathrm{k}$, of the Administration of Justice Act, which provides the possibility of initiating class actions in Denmark, provided certain criteria are met. C.I. Nagy, Collective Actions in Europe A Comparative, Economic and Transsystemic Analysis (2019), p. 81 and 88. 


\section{Discretionary certification justified?}

The United States, Ontario and the European jurisdictions mentioned herein employ a general type of class action for which prior court approval or certification is required. Clearly, these jurisdictions do not distinguish between circumstances in which certification is required. Simply put, if it is a class action, it must go through a process of certification, regardless of whether the class action is civil rights-based or whether it displays a public character.

In 1998, with reference to the recommendations contained in the Working Paper, ${ }^{101}$ the South African Law Commission (SALC) published a report which inter alia recommended that the principles underlying class actions should be introduced by an Act of Parliament and the necessary procedures by rules of court. ${ }^{102}$ The SALC in its report did not limit its recommendation that class actions should go through a process of certification to certain types of class actions only. According to the SALC, '[i]n class actions a preliminary application should be brought before court requesting leave to institute or defend an action as a class action and to ask for directions as to procedure'. ${ }^{103}$

According to De Vos, Jafta J's obiter dicta in Mukaddam 'speaks of a misunderstanding'. ${ }^{104}$ De Vos states that certification is necessary to enable the court to properly deal with the procedural issues that arise during the early stages of class proceedings inter alia to ensure that the interests of the absent members are protected. For example, since the absent members are not parties to the suit, it should also be shown that the representative will adequately look after their interests in the proceedings. According to De Vos, the same issues must be considered in the case of a class action to enforce constitutional rights against the state. ${ }^{105} \mathrm{He}$ further states that what Jafta J perhaps had in mind is that certification should not be applicable in the case of a public interest action to enforce constitutional rights, which is correct as there are important procedural differences between class actions and public interest actions. In the latter context, notice to the public is not required and the judgment on the merits does not have res judicata effect. ${ }^{106}$

It is indeed the case that those considerations that apply in class action based on nonconstitutional rights would generally apply to class actions used to enforce constitutional rights against the state or against private persons, or to those with a public character. Regardless of the nature of the claim, considerations such as the class definition, the suitability of the legal representatives and the appropriateness of class proceedings remain relevant. There is no reason why these considerations would not be applicable to those types of class actions. Moreover, the need to avoid abuse of the mechanism, to avoid pitfalls associated with the non-certification regime of Australia, and to ensure to benefits of certification extend to such cases, make certification in those cases vital. ${ }^{107}$

101. South African Law Commission, 'The Recognition of a Class Action in South African Law', Working Paper 57, Project 88 (1995). At the time it was known as the South African Law Commission. It became the South African Law Reform Commission in 2002.

102. South African Law Commission, 'The Recognition of a Class Action in South African Law', Working Paper 57, Project 88 (1995).

103. Ibid., p. 40.

104. W. de Vos, 4 Journal of South African Law (2013), p. 767.

105. Ibid., p. 766-767.

106. W. de Vos, 4 Journal of South African Law (2013), p. 766-767; The South African Law Commission, The Recognition of Class Actions and Public Interest Actions in South African Law Report, Project 88, (1998), p. 8.

107. Trustees for the time being of the Children's Resource Centre Trust v. Pioneer Food (Pty) Ltd. (Legal Resources Centre as amicus curiae), 20131 All SA 648 (SCA), para. 24; Nkala and others v. Harmony Gold Mining Company Limited, [2016] 3 All SA 233 (GJ), para. 38. 
There is no conceivable basis upon which it can be concluded that in Bill of Rights class actions against the state or private persons, as opposed to other types of class actions, the need to use prior certification 'as an instrument of justice' and 'to keep out of the justice system class actions which hinder, instead of advancing, the interests of justice' dissipates. ${ }^{108}$ The interests of justice should always be considered before a court permits a class action to proceed, even when it is a class action instituted in terms of section 38(c) of the Constitution. This would entail traversing the factors identified by Wallis JA in Children's Resource Centre Trust. Jafta J in Mukaddam correctly states that 'class actions in which the enforcement of right entrenched in the Bill of Rights is sought against the State' assumes a public character, which necessarily widens the reach of orders issued to cover persons who weren't privy to the litigation. ${ }^{109}$ However, this does not detract from the importance of ensuring that permitting the class action would not be 'oppressive' and 'inconsistent with the interests of justice'. In fact, the widened reach of such orders underlines the importance of prior certification as an instrument of justice.

In Nkala, the court held as follows regarding the non-restricted imposition of the certification requirement in Children's Resource Centre Trust:

Since the pronouncements of the SCA in Children's Trust, a class action can only proceed to trial if it has been certified by the court as being an appropriate means of resolving the dispute between the putative class members and the defendant(s). The SCA did not, however, restrict this prerequisite to cases where no right in the Bill of Rights has been invoked. The SCA stated that certification is necessary for the court to be satisfied that certain conditions (the court as we know referred to them as 'requirements') are met justifying the burdening of the defendants and the court with a class action, as well as binding the putative class members with a judgment that finally resolves all, or some, of the issues between the parties. ${ }^{110}$

The court in Nkala accordingly found that the certification factors would still need to be considered, irrespective of the nature of the proceedings and the imposition by the Constitutional Court of the 'interests of justice' principle. Similarly, in Pretorius and another v. Transnet Second Defined Benefit Fund and others ${ }^{111}$ the court confirmed with regard to Mukaddam and Children's Resource Centre Trust that 'the Constitutional Court endorsed the approach set out by the Supreme Court of Appeal and in addition thereto the Constitutional Court laid down the principle applicable for certification, to wit, the interests-of-justice principle'. ${ }^{112}$ In National Union of Metalworkers of South Africa v. Oosthuizen and Others ${ }^{113}$ the court also held that 'the seven factors identified in Children's Resource Centre form the building blocks of the founding affidavit in this matter. Provided the overarching 'interests of justice' lodestar remains the vade mecum, these seven factors are justifiably traversed, and they must be applied to the facts of the present case'. ${ }^{114}$ Finally, and most recently, in Vlok and Others $v$. Georgiou and Others, ${ }^{115}$ the court confirmed with

\footnotetext{
108. Mukaddam v. Pioneer Foods (Pty) Ltd., 201310 BCLR 1135 (CC), para. 38.

109. Ibid., para. 40.

110. Nkala and others v. Harmony Gold Mining Company Ltd and others (Treatment Action Campaign NPC and another as amici curiae), [2016] 3 All SA 233 (GJ), paras. 35-36.

111. Pretorius and another v. Transnet Second Defined Benefit Fund and others 2014 (6) SA 77 (GP).

112. Ibid., para 23.

113. National Union of Metalworkers of South Africa v. Oosthuizen and Others, 2017 (6) SA 272 (GJ).

114. Ibid., para. 23.

115. Vlok and Others v. Georgiou and Others, 20201 All SA 884 (GP).
} 
reference to the factors listed in Children's Resource Centre Trust that '[i]n order to establish whether this application should be granted and the class action be certified, it is appropriate to consider the factors set out above, the interests of justice and any factor that may be relevant to this specific application'. 116

The point of departure for class proceedings is accordingly to consider whether certification would be in the interests of justice, which would clearly entail considering the factors identified by Wallis JA in Children's Resource Centre Trust. For example, the certification factors include that there must be a class, identifiable by objective criteria, and it must be shown that a class action is the most appropriate means of adjudicating the claims of the class members. ${ }^{117}$ A proper class definition inter alia enables the court to determine how notification to the putative class members should take place, to decide who does not form part of the class and may accordingly institute individual actions, and to establish who will be bound by the court's order. ${ }^{118}$ The factor that a class action must be appropriate is, according to Erasmus and Van Loggerenberg, aimed at ensuring that only claims that cannot feasibly be instituted as ordinary actions with multiple plaintiffs are brought as class actions. ${ }^{119}$ Just as these issues, for example, would need to be considered in the context of a non-constitutional rights class action, it would also arise in a Bill of Rights class action pursued against the state or against private persons.

In order to determine whether a class action is in the interests of justice, the court would also need to consider whether certification of the class action is necessary to achieve access to justice. ${ }^{120}$ If it is not necessary to achieve access to justice, it is likely that class proceedings are inappropriate and that certification would not necessarily be in the interests of justice. Essentially, this consideration entails determining whether there are any potential barriers to access to justice, the existence of which can effectively be addressed by certification of a class action. ${ }^{121}$ Possible barriers to access to justice include the geographical dispersion of class members, the inability of

116. Ibid., para. 44

117. Trustees for the time being of the Children's Resource Centre Trust v. Pioneer Food (Pty) Ltd. (Legal Resources Centre as amicus curiae), 20131 All SA 648 (SCA), para. 26.

118. H.J. Erasmus and D.E. van Loggerenberg, Superior Court Practice (2nd edition, Juta, 2013), A2-23.

119. Ibid., A2-25.

120. T. Broodryk, 'The South African Class Action vs Group Action as an Appropriate Procedural Device', 30 Stellenbosch Law Review (2019), p. 6-32. See also, for example, in Excalibur Special Opportunities LP v. Schwartz Levitsky Feldman LLP 2007 ONCA 334, 85 OR (3d) 321 para. 217; Perell J held that it was not shown that 'a class action is necessary to overcome any barriers to access to justice'.

121. In the Ontario Law Reform Commission, Report on Class Actions (Ministry of the Attorney General, 1982), p. 121 it is stated that class actions can help overcome barriers to access to justice and may accordingly perform an important function in society. In Excalibur Special Opportunities LP v. Schwartz Levitsky Feldman LLP, 2007 ONCA 334,85 OR (3d) 321, para. 217 Perell J concluded that, on the facts, joinder was the preferable procedure inter alia because it was not shown that a 'class action is necessary to overcome any barriers to access to justice'. In AIC Limited v. Fischer, 2013 SCC 69, para. 24-38 it was held that a court must consider whether there are barriers to access to justice in the given case. In Ministry of the Attorney General, British Columbia, Consultation Document: Class Action Litigation for British Columbia (1994), p. 8, it was held that 'the opt out model is the more effective means to ensure that the barriers to justice, which class actions are intended to overcome, are reduced'. See also Alberta Law Reform Institute, Class Actions: Final Report (2000), p. 85 and 97; South African Law Commission, The Recognition of Class Actions Report, para. 5.11 and Permanent Secretary, Department of Welfare, Eastern Cape v. Ngxuza, 20014 SA 1184 (SCA), para. 4-6, where Cameron JA held that society cannot simply set up courts and wait for litigants to bring their complaints as barriers may exist that preclude their participation in litigious proceedings; hence, the need for class proceedings. 
claimants to engage in individualized litigation, and the difficulties associated with requiring litigation through joinder. For example, the more geographically dispersed the class members are, the less likely it is that they will engage in individualized litigation and the more impractical it is to join those class members. ${ }^{122}$ In such circumstances, a class action is likely to be more appropriate than joinder as a mechanism to adjudicate class members' claims. ${ }^{123}$

The inability of claimants to engage in individualized litigation is a further potential barrier to access to justice. This barrier entails consideration of various factors which may contribute to, or result in, the claimants' inability to institute and pursue individual suits, such as whether the class members are poor and whether they lack resources. ${ }^{124}$ The poorer the individual class members are, the more likely it is that they would be unable to litigate in the absence of certification of the class action. ${ }^{125}$ A lack of resources and the inability of class members to meet the costs of legal representation generally means that litigation through joinder would be too expensive. ${ }^{126}$ It is therefore likely that, in such circumstances, a court would conclude that a class action is appropriate. ${ }^{127}$

Certification also entails considering practical considerations that are otherwise relevant to determining the appropriateness of class actions. ${ }^{128}$ Courts should also consider the judicial economy that would arise if the multiplicity of actions were avoided as well as the necessity of class proceedings to effect behaviour modification. Achieving judicial economy would entail joining together a number of lawsuits that would otherwise have been brought separately. ${ }^{129}$ Behaviour

122. See, for example, Dameron v. Sinai Hosp. of Baltimore, Inc., 595 F. Supp 1404, 1408 (D Md 1984), aff'd in part and rev'd in part 815 F.2d 975 (4th Cir. 1987); In re Southeast Hotel Properties Limited Partnership Investor Litig, 151 F.R.D. 597, 601 (WDNC 1993). United Brotherhood of Carpenters and Joiners of America Local 899 v. Phoenix Associates, Inc, 152 F.R.D. 518, 522 (SD W Va 1994).

123. According to B. Anderson and A. Trask, Class Action Playbook (Oxford University Press, 2014), p. 27, if the class is limited to a specific geographical territory it is likely that joinder would be feasible.

124. See South African Law Commission, 'The Recognition of a Class Action in South African Law', Working Paper 57, para. 5.25, where it is stated that a large portion of South African society is poor, illiterate and ignorant because they have not received a quality education and that the need to ensure that such people benefit from class actions is greater in South Africa than in certain other foreign jurisdictions.

125. In Lake v. First Nationwide Bank 156 FRD 615, 625 (E.d.Pa. 1994) it was held that, in performing the superiority analysis in terms of rule 23(b)(3) of the Federal Rules, the court must consider the 'inability of the poor or uninformed to enforce their rights, and the improbability that large numbers of class members would possess the initiative to litigate individually'. Similarly, according to Cameron JA in Permanent Secretary, Department of Welfare, Eastern Cape v. Ngxuza, 20014 SA 1184 (SCA), para. 6, because there are so many poor individuals in South Africa who do not have the necessary resources to litigate, the attainment of justice could be unduly complicated. See also M. Nyenti, 'Access to Justice in the South African Social Security System: Towards a Conceptual Approach', 4 De Jure (2013), p. 914 where he states that '[o]ne of the factors restricting the right of access to courts in South Africa is the long distances that many people have to travel in order to access the courts and related services'.

126. See Gold Fields Limited and Others v. Motley Rice LLC, In re: Nkala v. Harmony Gold Mining Company Limited and Others, [2015] 4 SA 299 (GJ), para. 55, where Mojapelo DJP held that '[t]he positive impact of litigation funding agreements that no one can deny is that such agreements promote access to justice. The importance is elevated a step higher where the funded litigant is one who, because of poverty and lack of resources, would otherwise not have been able to litigate...'

127. In Robidoux v. Celani 987 F.2d 931936 it was held that 'the potential class members are distributed over the entire area of Vermont. They are also economically disadvantaged, making individual suits difficult to pursue ... Thus, the district court abused its discretion in determining that the class was not so numerous that joinder of all members would be impracticable'.

128. See Permanent Secretary, Department of Welfare, Eastern Cape v. Ngxuza, 20014 SA 1184 (SCA), para. 16.

129. See, for example, the approach in Ontario as set out in Excalibur Special Opportunities LP v. Schwartz Levitsky Feldman LLP, [2007] ONCA 334, 85 OR (3d) 321, para. 217 where Perell J held that it was not shown that 'a class 
modification would entail deterring potential defendants, who may otherwise have assumed that their minor wrongs would not result in litigation, from similar future wrongdoing. ${ }^{130}$

Apart from considering judicial economy and behaviour modification, the court should also consider any other practical consideration that may be relevant when determining the appropriateness of class proceedings. Such considerations could typically include the manageability of the class action; ${ }^{131}$ whether the class members' claims are large enough to warrant being pursued separately; ${ }^{132}$ and, the importance of the common issues in relation to the claims as a whole. The manageability of the class action entails taking into account inter alia the size of the class, ${ }^{133}$ the identifiability of class members ${ }^{134}$ and the extent of the non-common issues that would require individualized adjudication.

action is necessary to overcome any barriers to access to justice. In the case at bar, a class action is not necessary to achieve behaviour modification and a class action would not be particularly helpful in providing judicial economy.' See also Hollick v. Toronto (City), [2001] 3 SCR 158, para. 27-32; Markson v. MBNA Canada Bank, [2007] ONCA 334, 85 OR (3d) 321, para. 69-70; Excalibur Special Opportunities LP v. Schwartz Levitsky Feldman LLP, [2015] ONSC 1634, para. 26; AIC Limited v. Fischer, [2013] SCC 69, para. 24-38. In Bright v. Femcare Limited, [2002] FCAFC 243; 195 ALR 574, para. 152, Finkelstein J, for the Federal Court of Australia, held that whether or not it is in the interests of justice to make an order that the representative proceeding be terminated, requires consideration of the principal objects of the class action procedure. See also South African Law Commission, The Recognition of Class Actions Report, para. 5.11.3.

130. Western Canadian Shopping Centres v. Dutton, (2001) 2 S.C.R. 534, para. 29. See also R. Mulheron, The Class Action in Common Law Legal Systems: A Comparative Perspective, (Hart Publishing, 2004), p. 6.

131. For the type of considerations that could typically inform the manageability of the class action see, for example, B. Anderson and A. Trask, Class Action Playbook, p. 62; Eisen v. Carlisle \& Jacquelin, 417 U.S. 156, 164 (1974); Carnegie v. Mutual Saving Life Insurance Company, No. CV-99-S-3292-NE, 2002 U.S. Dist. Lexis 21396, 76-77 (N.D. Ala. Nov. 1, 2002); Hollick v. Toronto (City), (2001) 3 SCR 158, para. 32; Markson v. MBNA Canada Bank, [2007] ONCA 334, 85 OR (3d) 321, para. 69-70 and Excalibur Special Opportunities LP v. Schwartz Levitsky Feldman LLP, [2007] ONCA 334, 85 OR (3d) 321, para. 217.

132. In Trustees for the time being of the Children's Resource Centre Trust v. Pioneer Food (Pty) Ltd (Legal Resources Centre as amicus curiae), [2013] 1 All SA 648 (SCA), para. 19, Wallis JA mentions considerations that are relevant to determining the appropriateness of class proceedings compared to joinder, including considering whether the claims are large enough to warrant being pursued separately. See also Permanent Secretary, Department of Welfare, Eastern Cape v. Ngxuza, [2001] 4 SA 1184 (SCA), para. 4-5.

133. Regarding the numerosity requirement contained in rule 23 of the Federal Rules, the bigger the class the more likely it is that joinder would be impracticable. According to M.H. Greer, A Practitioner's Guide to Class Actions (2010), p. 58 it is generally accepted that 'when class size reaches substantial proportions ... the impracticability requirement and hence the numerosity requirement is usually satisfied by the numbers alone'. See also R.H. Klonoff, Class Actions and Other Multi-party Litigation in a Nutshell (2012), p. 131 where it is stated that, although courts are reluctant to certify classes whose members would be difficult to communicate with or identify, the sheer size of the class would not necessarily result in the denial of certification. Regarding section $33 \mathrm{~N}(1)$ (d) of the Federal Court of Australia Act of 1976, representative proceedings can be discontinued where it is 'otherwise inappropriate that the claims be pursued by means of a representative proceeding'. According to P. Cashman, Class Action Law and Practice (The Federation Press, 2007), p. 321, the size of the class is a relevant consideration to determine whether it is 'otherwise inappropriate'. In Nkala and others v. Harmony Gold Mining Company Limited, [2016] 3 All SA 233 (GJ), para. 52 Mojapelo DJP held that '[w] hat we have here is that the sizes of the two classes may be very large but that does not make the class definition overbroad or the class action trial unmanageable'.

134. According to R.H. Klonoff, Class Actions and Other Multi-party Litigation in a Nutshell (2012), p. 40, the approach of the United States is that the identifiability of individual class members will form part of the assessment of the impracticability of joinder. It is not the only consideration in determining the practicability of joinder compared to class actions. In Keatley Surveying Inc v. Teranet Inc, [2014] ONSC 1677, Sachs J held that, in Ontario, a plaintiff is only required to propose a class definition that provides for an identifiable class of two or more people - a plaintiff is 
The weight given to each of these factors should vary in proportion to those factors that form part of the access to justice consideration. For example, although the class members are identifiable, if the individual claimants are poor and therefore unable to litigate through joinder, a court should not find that the fact that they are identifiable makes joinder the appropriate means for adjudicating the claimants' claims. ${ }^{135}$

If a court certifies class proceedings on the basis that it is appropriate because it would inter alia faciliate access to justice, judicial economy and behaviour modification, it is likely that certification would be in the interests of justice, although the other factors identified by Wallis JA would still need to be considered.

Brickhill and Bleazand agree that there are conceptual problems with Jafta J's finding in Mukaddam. 'Maintaining a sharp distinction between Bill of Rights claims and non-Bill of Rights claims sustains an artificial divide between the common law and the Constitution that the Constitutional Court has long since rejected. ${ }^{, 136}$ They state that:

Jafta J's suggestion that s 38 of the Constitution may require a different treatment of class actions instituted against private parties is also perplexing, since s 38 has been applied both vertically and horizontally, and nothing in the text of $\mathrm{s} 38(\mathrm{c})$ suggests that this sub-section ought to be applied differently. ${ }^{137}$

Brickhill and Bleazand argue that the decision of whether certification is required should not be based on the distinction between Bill of Rights/non-Bill of Rights litigation or the public/private character of the litigation. Rather, a purposive approach should be adopted, which entails considering 'whether, in the context of the relief sought, the nature and composition of the class and the claims sought to be prosecuted, certification will facilitate the litigation, protect the litigants or otherwise advance the interests of justice'. ${ }^{138}$ This would entail requiring certification in class actions where individualized relief, including damages, is sought on behalf of a class and in cases where not all class members are known. They contend that certification will serve no compelling purpose if an order in the nature of an interdict or review that will apply equally to all members of a class is sought. ${ }^{139}$

The above-mentioned approach puts forward the possibility of using a procedural framework for class certification that may vary depending on the relief requested and the rights that are at stake, rather than certification being an all-or-nothing proposition. The difference between the above-mentioned proposed purposive approach and the actual certification process appears to be

not required to establish the actual existence of two or more potential class members. See also N. Kirby, 'South Africa', in P.G. Karlsgodt (ed.), World Class Actions - A Guide to Group and Representative Actions around the Globe (Oxford University Press, 2012), p. 58; B. Anderson and A. Trask, Class Action Playbook, p. 26; and section $33 \mathrm{H}(2)$ of the Federal Court of Australia Act of 1976.

135. See Permanent Secretary, Department of Welfare, Eastern Cape v. Ngxuza, [2001] 4 SA 1184 (SCA), para. 4-5.

136. J. Brickhill and J. Bleazand, 'Bill of Rights Class Actions', in M. du Plessis et al. (eds.), Class Action Litigation in South Africa (Juta, 2017), p. 73; see also W. de Vos, Journal of South African Law (2013), p. 767; De Vos (2012, Juta), p. 747: 'The distinction between class actions to enforce constitutional rights and class actions to enforce nonconstitutional rights is not always clear. The cases often do not all fall neatly into either of these two categories simply because the plaintiffs sometimes rely on the infringement of both constitutional and non-constitutional rights'

137. J. Brickhill and J. Bleazand, in M. du Plessis et al. (eds.), Class Action Litigation in South Africa, p. 73.

138. Ibid.

139. Ibid. 
negligible. Ultimately, in both cases, it would be necessary to determine where the interests of justice lie in relation to certification. The factors that a court would need to consider to determine whether to require certification would not be much different to the factors listed by Wallis JA in Children's Resource Centre Trust. For example, apart from having to consider inter alia the class definition and whether the cause of action raises a triable issue, the court won't be able to decide not to require certification without considering whether it is an appropriate mechanism to adjudicate the dispute i.e. whether it would facilitate access to justice and whether it is in the interests of justice (or would 'otherwise advance the interests of justice'). ${ }^{140}$ It is also important to bear in mind that the certification factors identified by Wallis JA in Children's Resource Centre Trust overlap to some extent; for instance, it is not possible to determine class composition without considering the nature of the claim. Wallis JA added that a class action may be appropriate where the class members share common issues, but that it is not necessarily the case. He further held that it is conceivable that a class action could be certified in respect of some issues, such as negligence in a mass personal injury claim, with the result that other issues, such as damages, would need to be resolved separately. ${ }^{141}$ In other words, if a court decides that the interests of justice favours the imposition of a certification requirement, it is unlikely that a court would decide not to certify the class action, as similar considerations would apply.

One of the purposes of certification entails ensuring that there is no abuse of court process. This purpose remains operative regardless of the nature of the relief sought in class proceedings. As indicated in Nkala, this applies to all class actions, including Bill of Rights class actions. ${ }^{142}$ Furthermore, absent parties' interests must in all class actions be found to be properly represented. Also, certification does not only operate to the benefit of the putative class; the defendant(s) should be afforded the opportunity to dispute the proceedings at the (early) certification stage. Accordingly, when a class action is instituted, it should always be subject to a certification process. Why does it become unnecessary in Bill of Rights class actions, or in class actions in which interdictory relief is sought, to ensure that the class representative is suitable and not conflicted from representing the class? Similarly, this author cannot conceive of circumstances where it would be unnecessary for a court to consider the class definition or whether class proceedings are indeed appropriate inter alia in light of a comparison with other procedural mechanisms at the applicants' disposal.

A selective approach, by only requiring certification of certain class actions, will hinder the development of a South African procedural class action framework, especially in the absence of legislation and/or rules regulating class actions. It may also increase uncertainty amongst judges regarding whether to require and how to approach class action certification, perhaps even result in apprehension amongst judges at the prospect of being tasked with adjudicating class proceedings. This could result in inconsistency in approaches across the various divisions of the High Court of South Africa regarding certification. Mshengu is a fitting example of the latter.

140. Ibid.

141. Trustees for the time being of the Children's Resource Centre Trust v. Pioneer Food (Pty) Ltd (Legal Resources Centre as amicus curiae), [2013] 1 All SA 648 (SCA), para. 26.

142. Nkala v. Harmony Gold Mining Company Limited, [2016] 3 All SA 233 (GJ), para. 38. 


\section{Conclusion}

The issue that is subject to determination is whether, in South Africa, there is a valid basis for requiring a process of certification of certain types of class actions only. To determine this issue, it is necessary to consider the purpose of certification and whether it would only be given effect to in certain circumstances. If certification would serve no purpose in the context of Bill of Rights claims or claims which display a public character, it may be prudent not to require class action certification in those cases. Conversely, if certification would still serve a purpose in those types of cases, it should remain part of class proceedings. This author is ultimately of the view that certification should be required in all class actions, regardless of whether it is instituted in terms of section 38(c) of the Constitution.

De Vos states, and this author agrees, that Jafta J's relegation of the requirements for a class action to mere factors under the umbrella of 'the interests of justice' is questionable. He states that:

[t]his flies in the face of the very nature of a class action and the position in the leading class action regimes. A class action is very different from an ordinary civil suit. For a class action to proceed as such certain essential requirements must be satisfied, otherwise it would be a travesty to call it a class action. $^{143}$

Wallis JA stated in Children's Resource Centre Trust that 'certification enables the defendant to show at an early stage why the action should not proceed', ${ }^{144}$ which opportunity should not be deprived from defendants on an ad hoc basis by the courts. Similarly, 'in view of the potential impact of the litigation on the rights of others it is necessary for the court to ensure at the outset that those interests are properly protected and represented'. ${ }^{145}$ It is also arguably compelling that certification would enable the court to oversee the procedural aspects of the litigation from the outset, including the manageability of proceedings. ${ }^{146}$ Judicial management is considered to be increasingly important for the effective functioning of civil litigation in general, and of the class action system in particular. ${ }^{147}$ Moreover, as class action litigation is traditionally more complex than other kinds of litigation, it requires greater administration and management of the case. ${ }^{148}$ Where manageability problems occur during the course of class proceedings, they could potentially result in the termination of the class action. ${ }^{149}$ These considerations, along with others

143. W. de Vos, 4 Journal of South African Law (2013), p. 765-766. According to the South African Law Commission, The Recognition of Class Actions and Public Interest Actions in South African Law Report, Project 88 (1998), p. 40, the generally accepted practice in other jurisdictions is that a class action may be commenced by a representative on behalf of the class, but within a specified time it must be certified by a court in order to proceed as such.

144. Trustees for the time being of the Children's Resource Centre Trust v. Pioneer Food (Pty) Ltd. (Legal Resources Centre as amicus curiae), 20131 All SA 648 (SCA), para. 24.

145. Ibid.

146. Ibid.

147. C. Piché, 'Judging Fairness in Class Action Settlements', 28 Windsor YB Access Just (2010), p. 121.

148. According to P.G. Karlsgodt, 'United States', in P.G. Karlsgodt (ed.), World Class Actions - A Guide to Group and Representative Actions around the Globe (Oxford University Press, 2012), p. 44, a tool that is regarded as useful in managing class action proceedings in the United States is to require the submission of a trial plan - a document that sets out the claim(s), the relief, the witnesses and evidence that will be used to prove the plaintiffs' claims at the trial. See also C. Piché, 28 Windsor YB Access Just (2010), p. 117.

149. In Eisen v. Carlisle and Jacquelin, 417 US 156 (1974), the enormity of the class and related issues such as notice to absent members and the distribution of an aggregate award to class members caused serious doubt about the viability of the case. 
mentioned herein, militate in favour of an approach which requires certification of Bill of Rights class actions.

Unfortunately, the Constitutional Court in its majority judgment in Mukaddam, by watering down the significance of the certification requirement imposed by Wallis JA in more than one respect, caused the procedural framework for the adjudication of class actions in South Africa to retrogress. This has resulted in inconsistent approaches by the South African superior courts. The views expressed in Mukaddam and Mshengu that Bill of Rights class actions against the state would not need to be certified is, with respect, incorrect. There is no justifiable basis upon which such a distinction can be made. The same applies in respect of Bill of Rights class actions against private persons. Certification clearly serves a purpose in the context of these class actions and should accordingly be employed consistently, across the board, irrespective of the nature of the class proceedings. In all class actions, South African courts should decide whether to certify class action with regard to the guiding criterion, namely the interests of justice, supplemented by consideration of the certification factors formulated by the Supreme Court of Appeal in Children's Resource Centre Trust. It is not necessarily ideal to employ an ad hoc approach in respect of procedural problems that arise on a case-by-case basis. ${ }^{150} \mathrm{~A}$ haphazard developmental approach to the regulation of class actions could potentially result in an inconsistent approach by the South African superior courts. ${ }^{151}$

\section{ORCID iD}

Theo Broodryk (D) https://orcid.org/0000-0003-2514-4951

150. Trustees for the time being of the Children's Resource Centre Trust v. Pioneer Food (Pty) Ltd (Legal Resources Centre as amicus curiae), [2013] 1 All SA 648 (SCA), para. 15.

151. See G. Saumier, 'Competing Class Actions across Canada: Still at the Starting Gate After Canada Post v. Lepine?', 48 Can Bus LJ (2009), p. 463. For example, Ontario allows certification of a resident and non-resident class on an opt-out basis and, as the number of provinces allowing class actions increased, the risk of competing and potentially overlapping actions grew and eventually materialized. This has led to inconsistent results. 